\title{
ANALYZING WHAT PERMANENT ACADEMIC CLASSROOM ACTIVITY OF ENGLISH TEACHERS TELL US ABOUT THEIR PROFESSIONAL DEVELOPMENT NEEDS: PRIMARY SCHOOLS IN FOCUS
}

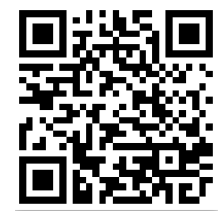

\author{
Melkamu Teklu Kisi ${ }^{1} \bowtie\left(D\right.$, Tamene Kitila $\operatorname{PhD}^{2} \bowtie$, Mekuria Zewdie PhD ${ }^{3} \bowtie$ \\ ${ }^{1}$ Addis Ababa Science and Technology University, Department of English, P.O. Box 16417, Addis Ababa, \\ Ethiopia \\ ${ }^{2}$ Addis Ababa University, Department of English, Addis Ababa, Ethiopia \\ Department of English, Nekemte, Ethiopia
}

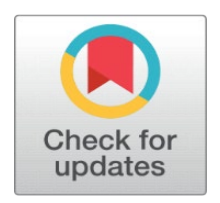

Received 07 January 2022

Accepted 06 February 2022

Published 28 February 2022

\section{CorrespondingAuthor}

Melkamu Teklu Kisi,

malkekoo@gmail.com

\section{DOI 10.29121/ijetmr.v9.i2.2022.1057}

Funding: This research received no specific grant from any funding agency in the public, commercial, or not-for-profit sectors.

Copyright: (C) 2022 The Author(s). This is an open access article distributed under the terms of the Creative Commons Attribution License, which permits unrestricted use, distribution, and reproduction in any medium, provided the original author and source are credited.

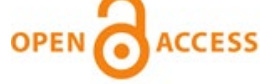

\section{ABSTRACT}

The present study analyses what permanent academic classroom activity tells us about the professional development need of English language teachers in primary Schools. Teacher classroom observation was used as data gathering tools for the study. As a result, four English language teachers were involved in the study. The study was conducted in selected primary schools in North Showa Zone of Orimia Regional State. The four teachers involved in the study were observed three times. The results of the study reveal that teachers lack English language proficiency. Their classroom English lacked quality to use the target language. So, they needed to develop their English language proficiency. The result of the study further showed that the teachers needed to develop their pedagogic skills. The pedagogic skills the English language teachers needed to develop were lesson opening, lesson running and lesson ending strategies. Similarly, the teachers needed professional development on the areas of language use and transitioning and questioning strategies. Based on the finding of the study, it was suggested that English language teachers in primary schools needed to get further professional development program that addresses their linguistic knowledge and skills need areas so that the teachers improve their proficiency in the target language and enhance their skills in teaching.

Keywords: Permanent Academic Activity, Language Use, Professional Development, Skills in Teaching

\section{INTRODUCTION}

Continuous Professional Development (CPD) is the concept and practice of ongoing structured lifelong learning of professionals in the teachers' development needs Minae and David (2017). their finding indicates that CPD is a necessity for teachers to fully engage with their development. They state that English teachers choose professional development activities relevant to their development need for development so that they discover new opportunities, develop their linguistic knowledge and the pedagogic skills. According to them, when English their professional development needs are considered, they would increase their overall understanding of the target language in genuine interactive situations. Because professionally developed teachers can apply classroom teaching practices to help students understand 
and use English language appropriately Minae and David (2017). This means with increasing English proficiency; teachers also tend to use language teaching strategies that allow them to facilitate language use and interact more effectively with their colleagues and students.

Assessing and identifying professional development (PD) needs of primary English language teachers have never received significant interest at the global level Zein (2015). However, plenty of studies have explored the role of teachers in the classroom Richards (2006). Previous studies have focused on identifying pedagogical concerns, like assessing learning outcomes (Wang, 2002), implementation of communicative language teaching to develop teachers' profession Butler (2015), Desta et al. (2013), school based CPD in Addis Ababa; Clark (2018), key challenges and pedagogic implication; incorporating corrective feedback Zhao (2009), the kinds of challenges that teachers encounter in their classrooms Cheng (2010), effective professional development strategies of English language teachers by Hismanoglua (2010). This means there has been little, or no research conducted on what the actual teaching practices report about teachers' professional development needs. This has motivated the study.

In Ethiopian few studies were conducted on teacher professional development. For example, Fekede and Pavi (2015) study professional learning of teachers in Ethiopia. His major study focused on the challenges and implications of reforms in education. Although Fekede and Pavi explore potential and actual barriers that hinder TPD in Ethiopian schools, the study entirely reports about professional learning. Similarly, Workneh and Tassew (2013) explored teacher training and professional development in Ethiopia. In their findings, they pointed out that education quality can be improved by developing teachers' skills, attitudes, and work conditions. From this study, one can understand that teachers' development is one of the key factors in delivering quality education. The implication of this is teachers seek development in the areas of the profession.

Similarly, a study on teacher induction and the CPD in Ethiopia by Tadele (2013) shows teachers need professional development program to enhance their classroom practices. Supporting this finding, Desta et al. (2013) point out that school based CPD is used to enhance teachers' knowledge of the subject and skills in teaching. In their study, they focused on the importance of school based CPD in general. Similarly, Rukya (2016) reveals that a study on female teachers' professional development was not conducted. She recommends that action research is helpful method to develop teachers' knowledge. This means that the studies conducted so far have not considered what teachers actually do in the class. What teachers' classroom teaching practices tell us about the teacher's professional development needs has not yet been explored. This study was motivated to fill the gap in this regard.

In order to help us understand potential problems in English teacher development is vital to explore the overall trends and practices of the English teachers in primary schools. Despite the fact that numerous studies have investigated the various aspects professional development of teachers, a plethora of research on teachers' professional development needs has not yet been done. Little or no empirical research has devoted to study need- based professional development of teachers. This means that many of the studies so far have not focused on exploring teachers' professional development needs. The present study was motivated to explore what teachers' classroom practices talk about the teachers' language use and skills in teaching. 
Studies conducted outside of Ethiopia, for example, Eba (2013) and Desta et al. (2013) discuss school based professional development activities are not effective due to various reasons; for example, they ignore needs and expectations of teachers. Their findings further reveal that lack of professional development opportunities to practice is also another challenge. Naom (2013) reports that most professional development of teacher of today is ineffective due to its inabilities not only to bring changes in teacher practice in classroom but also to improve student learning in class. In connection with this, Eba (2013) states that teachers CPD programs were not designed to match with what the teachers are required to have in order to teach upper primary school levels. Eba elaborates that teachers' classroom performance do not have confidence in a wide range of English language and academic levels found in the classroom. This study was planned to fill this gap.

In their study about English language instructors' professional development needs, Eksi and Cape (2012) states that primary school teachers lack content knowledge and pedagogic skills that respond to their professional development need. Their finding reveals that teachers' lack of content knowledge and the pedagogic skills. This means the teachers are ineffective. Similarly, most of the studies in Ethiopia, for example, Clark (2018) reports that the contents of the schoolbased CPD were not designed to fit professional development needs of all teachers. This means the contents of the lessons were not designed according to the professional development need of the teachers.

Their study further shows the contents of English language improvement program (ELIP) and school based CPD activities are not fully relevant to the teachers' professional development needs. They further explained that there has been inappropriate balance between the national educational reform and individual teacher's professional development needs. Abraham (2018) holds a similar opinion in stating that CPD activities were not sufficient enough to equip teachers with the professional support they sought. Eba (2013) also points out that English teacher's poor competence and proficiency in the English have to be a priority concern. He recommends the need to explore professional development what English language teachers in primary school do in the classes. This means, so far, no literature has explored what permanent classroom activities like in the classes. Partly, the present study is part of the attempt to fill this gap.

Reports from different government offices reveal that the performance of the schools so far regarding CPD is not satisfactory (Haromaya University, 2007, (MOE) (2013), (MOE) (2014). The CPD programs in the schools are not achieving the desired objectives by improving student achievement. Dereje (2015) holds a similar opinion when he reports that the CPD practices at school do not have the basic features of successful teacher professional development. His finding also shows the CPD program is not strongly linked and engaging the teachers. That means the CPD activities designed do not address the teacher's classroom situations. Not addressing teacher professional development needs to enhance classroom activities may result into a mismatch between teachers' teaching goals and the students' leaning needs.

Future Search Conference's (2012) held at Ambo University reveals that there are direct relationships between teacher professional development and students' academic engagement. The report, however, did not discuss anything related to what English teachers needed to develop professionally. That means main focus of the report was not need based professional development of teachers. Similarly, Zein (2016) indicates that what teachers actually do in the class and their quality of language use has not received significant attention. Inadequate English language 
proficiency in the classroom was observed here and there in Ethiopia. This can be due to that fact that quality education has been deteriorating and students' achievement is declining Fekede and Fiorucci (2012), Lemlem (2010) and Tessema (2006).

To this end, strategies and programs were needed to develop teachers through continuous professional development so that teachers develop their linguistic knowledge and the pedagogic skills. Other programs in the package that were also introduced to enhance teacher development program include 'English Language Improvement Program (MOE) (2010), National Education Assessments (NEAs), Education Sector Development Programs (ESDP) I and II (2000, 2004 and 2007) respectively. The programs focus on providing in-service training for teachers in the primary and secondary schools for a relatively short period of time. The training emphasizes on improving teacher quality and increase teachers' classroom performances (MOE) (2005). Despite these efforts, however, many English language teachers do not speak English at an operational level. Apparently, teachers' poor language skills and their lack of access to appropriate professional development needs have made it difficult for them to create an effective learning environment for their students.

To creating an effective learning environment for the students, Ministry of Education in Ethiopia (MoE) established English Language Improvement Program (ELIP) in 2003. The ELIP focused on creating interactive, engaging in learning practical and relevant courses for teachers to help them meet their Continuous Professional Development (CPD) needs. However, it has not yet achieved the desired result (MoE, 2007). That means although the program was designed to develop teachers' knowledge and skills in teaching to a new level, the development of teachers has not been successful as desired.

The Profile of primary school English language teachers in Ethiopia tends to show that mainly, students who were not able to join university would join teacher education. Worse still, the pre-service training given to them does not enable them to be proficient enough to teach English. The training does not equip the teachers with the linguistic knowledge and the pedagogic skills they are required to have to teach English in primary schools. Observations and informal discussions with the teachers also show that they have poor command of English. This means they do not have the needed knowledge of the subject they are teaching, and pedagogic skills required to teach English. This inadequate background makes it necessary for the teachers to be given opportunities for CPD that address their needs for development. Indeed, MOE's introductions of different reforms and CPDs in the past for various years have given a long way to address the problems. However, it leaves much to be done yet to improve the situation.

Informal communication and observations the researcher had with primary school English language teachers indicates that the teachers find it difficult to do lessons well in the textbook in use (Grades 5-8). That means they lack linguistic knowledge and the pedagogic skills they are required to have in order to teach English in primary students. Available evidence also shows that several students complete primary school with significantly limited English language use skill. The students also complete secondary school and join university without much improvement in their English language use. This happens in spite of their use of the English language as a medium of instruction in the secondary school and university. This observation has given rise to the need to study the classroom practices of primary school English teachers. 


\section{OBJECTIVE OF THE STUDY}

The objective of the study was to analyse what permanent academic classroom activities of English language in primary schools tell us about their professional development needs.

\section{THE RESEARCH QUESTION}

The study was conducted to address the following research questions.

What do permanent classroom activities tell us about teachers' professional development need areas?

\section{THE PARTICIPANTS OF THE STUDY}

The study involved English language teachers in primary schools of the selected study area. The study was conducted at North Showa Zone of Oromia regional State in Ethiopia. All the study participants were informed about the objective of the study and the data collection processes began after agreement with all of them.

\section{THE DATA COLLECTION}

In this study, the primary purpose of conducting classroom observation was to address the basic question that the study addresses. This means the classroom observation was conducted to gather data about what the English language teachers did well and could not do well enough on permanent academic classroom activities that involve the use of English language in the classes. The permanent academic classroom activities include teacher lesson beginning, lesson running, lesson ending, classroom interaction, and classroom management. The intention was not to criticize the teachers' classroom practices, but to identify gaps where further professional development is needed to develop the English language teachers in primary schools.

To identify the gaps, the lessons were carefully observed from the beginning to the end of the periods and the units for each category were noted down. The classroom observations were conducted for 30 minutes long. In order to conduct classroom observation, four English teachers (two grades 5 and two grade 7) were selected. This means twelve classroom observations were conducted to collect data for this study. Codes were given to the teachers whose classes were observed. For example, T1, T2, T3, and T4 codes were given to the teachers whose classes were observed. The observation was held for 30 minutes. To get appropriate data on the teachers' classroom practices, the four English language teachers were observed four times at different period of time in the 2020/2021 academic year.

\section{ANALYSIS OF CLASSROOM OBSERVATION DATA}

The analysis of the data collected was analyzed qualitatively. Themes emerged during classroom observation data were coded initially first and then developed into focused codes. The data obtained from the four (T1, T2, T3 and T4) teachers of English which were observed three times were then developed into focused themes. 
Then the focused themes supported by theories regarding the focused themes were developed into theory.

The data were collected to obtain relevant data during teacher lesson opening, running, ending, and giving instruction. The data obtained were sampled as follows.

T1: Who can tell me what our yesterday's lesson? It is about -ing forms of the

verbs. Today we learn about word formation.

T2: Who can tell me what our yesterday's lesson is? It is .......

T3: Yesterday our topic of the lesson is?

T4: What did we learn yesterday? -ing. Right? We learnt verb-ing. What is the ing form of 'look'? 'Eat'? 'Come’? 'Turtu? Milki? Chala?

Ss: Looking, Eating and Coming.

Again, let's see the extract below taken during the second observation time of the teacher.

T1: Word Formation. Who can tell me what word formation? Copy this one to your exercise.

T2: Yesterday our topic of the lesson was? It is verb -ing form of the verb.

T3: Make a group in three. Then tell each other the main points of the yesterday's lesson. (Gave some time to the students to think the answers).

T4: Take the note. All of you copy it to your exercise book.

Let us see the extract from the three teachers again: OT1, OT2, OT3 were observed as follows.

T1: Who can tell me what word formation?

T2: Yesterday our topic of the lesson was? It is verb -ing form of the verb.

T4: Take the note. All of you copy it to your exercise book.

Nearly, similar data were sought during the third classroom observation time. Let us see the extract again.

T1: Yesterday our topic of the lesson is? Who can answer this question?

T2: Word Formation. Who can tell me what word formation? Copy this one to your exercise.

T3: Make a group in three. Then tell each other the main points of the yesterday's lesson.

T4: Take the note. All of you copy them to your exercise book. The lesson is 13: Revision Exercise. Today, we start Unit 10: The topic is "who is your nephew": Listening and Speaking: Study Picture. Open your book at page 131.

So far, the classroom observation data obtained related to what teacher classroom activities tell us about their professional development needs have been reported. In the next section, themes that have evolved from the responses of the study participants would be brought together and analyzed. The analysis would give us what the teacher classroom activities tell us about their professional development needs. 


\subsection{ANALYSIS OF PERMANENT CLASSROOM ACTIVITIES}

This section presents permanent academic classroom activities of the English language teachers. These activities include teacher lesson opening, running, and ending. Besides, this section discusses other activities the teachers use to deliver the lessons.

\subsection{TEACHER LESSON OPENING}

The English language teachers were observed with while their English language proficiency was weak. Their communication skills in English language were observed poor. This means their English language skills were not good enough to help students achieve the desired lesson objectives. The data showed that the teachers' lesson opening strategies were poor. They did not use quality language to open their lessons well. This means the teachers needed the linguistic potential and the pedagogic skills needed to achieve the desired lesson objectives.

The classroom observation data show that the teachers' lesson opening strategies were poor. This poor quality of the English teachers' language use may be because they lacked the linguistic potential needed to deliver lessons well, or the ways they were trained during their college time affected them or they did not know the importance of lesson opening, or they did not know the strategies they could use to open the lessons well. These ways of opening lessons do not encourage the learners to get motivated towards the lessons. The data showed that the teachers did not apply what (Richards \& Lockhart, 1994) called lesson opening strategies. This finding is consistent with Watson (1997). Watson holds a similar opinion when he also states that the strategies of lesson opening are used to motivate students to use their background knowledge. They strategies as Watson reports are that the teacher opened the lessons did not achieve the designed objectives.

Scrivener (2012) points out that the opening or beginning of the lesson plays a significant role in the lesson. It seems to be the moment that the teacher can decide whether the learners would be engaged in the lesson or not. Scrivener claims that if something goes wrong at this stage, it can affect the rest of the lesson. This implies that it is important to attract students and cultivate their desire for learning at the beginning of the teaching. Lindsay (2006) discusses that in the opening of the lesson, the teachers should explain to the learners about the aims of the lesson, and how the lesson links to previous ones and what activities they are going to do. Similarly, a lesson opening is the first phase of a lesson structure. Clark (2018) states that lesson opening takes the first 3-5 minutes of the lesson when teachers start to interact with students, and it is the commencement of the first major activity. Teacher lesson opening plays a significant role in the lesson as it could determine whether learning would occur. In contrast, previewing aims at preparing the students for the new lesson by raising their expectation of what will happen (Richard \& Thomas, 2005).

\subsection{THE NATURE OF THE TEACHERS' LESSON RUNNING}

T1 and T2 were observed while they were teaching '-ing form of Verbs' but the T3 was observed while teaching word formation. T4's class was observed while teaching reading passage. The passage was Gebeta. They asked the students to tell the class about words containing -ing. It was observed that the students were actively participating in telling the teachers verbs containing -ing. The teachers 
wrote their answers on the blackboard. T1, T2 and T3 used similar questions to ask the students. The extracts from $\mathrm{T} 1$ and $\mathrm{T} 2$ were taken as follows.

T1 and T2: Tell me a word that have -ing. Tell me. Tell me. Who? Milki: working

T3: Who will tell me words containing verb-ing? Habatamu? Ayele?

Habtamu: studying

Ayele: Looking

The data reveal that the observed teachers called their students with their names to answer the questions. Although the teachers nominated one or two students, almost the students handed up to get the chances to answer. This reveals that students' participation was high. The implication is the teachers did well enough in the observed classes. This shows that the teachers already know the importance of calling students in their names when they ask questions. Brown (2001) points out calling students in their names fosters a more interpersonal relationship, removes language barriers, and puts students in a better position to take charge of their learning and feel more confident to question their teachers.

Similarly, Willemsen (1995) states many successful educators agree that learning students' names is fundamental to developing a sense of community in the classroom. Willemsen further points out that a teacher that does not take the time to learn their students' names is often perceived as disinterested and unapproachable. This means by calling on a student by name, it gives the impression that the teacher cares about their success and develops a sense of trust. This also has an effect on student interactions. A study by Syverud (1993) points out that knowing the names of students promotes interaction. Syverud also states that when the professor engages the student in personal conversation, recognizes the students by names, and seems to include them in the domain of attention, the subject matter seems more accessible. The teacher would do more if he or she is provided skills training in teaching.

Let's us look at the following extract again:

T1 and T2: who will tell me a word that have -ing. Tell me. Who?

T3: Who will tell me words containing -ing? Habatamu and Ayele?

Although T1, T2 and T3 had very good student participation, the observation data reveal they did not do well enough on grammar usages when they asked the questions. They lack the grammar knowledge needed to use appropriate subjectverb agreement. This means the teachers do have problem of applying Subject-VerbAgreement. The teachers' use of singular subject (a word) with the plural verb (have) shows the teachers have grammar problems. Had the teachers used "Tell me words that have -ing" or "Tell me a word that has -ing", they would have been correct.

Similarly, the teachers' use of will was also inappropriate. The teachers used the simple future tense to talk about the activities going now. This shows that the English language whose classes were observed had difficulties with the use of tenses. Had the teachers got professional development programs that address their development need on language use, they would have performed well enough in the classroom.

The data reveal that the teachers seek appropriate grammar when they teach, instruct, the teachers are required to develop professionally on grammar lessons. 
Had the teachers used "...word that has...or ...words that have, it could have been better. The implication of this means that the teachers are required to get further development courses on subject- verb agreement. Offering the teachers with further training courses on grammar lessons would equip the teachers with the knowledge they needed to teach English.

The observation data also reveal that the teachers wrote words containing -ing on the blackboard and instructed students to copy the words from the board. Here is an extract from of the teachers' lesson running.

T1 and T2: Here are two examples of words containing '-ing'. Keep quiet. What is the '-ing' form of Learn?

$$
\begin{aligned}
& \text { Learn + -ing become learning } \\
& \text { Study + -ing become Studying } \\
& \text { Read + -ing is Reading. }
\end{aligned}
$$

T3: Tell me the -ing form of read, study, come and go" Almaz, can you answer the - ing form of Read?

\section{S1: Reading.}

T1 and T2: Excellent. Chala, what is the -ing form of the study?

S2: Studying.

T1 and T2: Very Good. Who can tell me the -ing form of come? Burtukan?

S3: Coming.

The data show that $\mathrm{T} 1$ and $\mathrm{T} 2$ asked the students the questions. But they become askers and answerers of the question. The students could have done by themselves to find the answers which the teachers required them to solve. This seems the teachers poorly performed the lesson. This might be due to teachers' lack of the knowledge or pedagogic skills they are required to apply to enhance classroom activities. Similarly, it implies that the teachers played dominant roles in the English classes. Further professional development training courses on students centered method of teaching English language would equip the teachers with knowledge and the skills they are required to apply in the classes.

After the class, T1 and T2, T4 were asked to reflect on why they did not allow students to try out the -ing form of the words they were given. The teachers reflected that if they were given this opportunity, the students would disturb by shouting loudly. From the teachers' reflections, one can observe that the students' lack of discipline and attention during the lesson are some of the challenges that had worried the teacher. My observation data of the classes reveal that no noticeable disruption in the progress of the lesson occurred when the teachers form the -ing form of the words themselves. This implies that the T1, T2 and T3 did not do well enough in allowing the students to discuss the question and to find the answers by themselves. Therefore, continuous professional development courses on active learning strategies of teaching English will equip the teachers with the required pedagogic skills.

In T3's and T4's lesson, the introduction included explicit framing of the lesson objectives. Here is an extract from the lesson opening:

T4: Who can tell me our previous lessons? No one? Hand up if you want to answer. 
No? Ok! Work in group now. Open your book on page 98.

There was no defined closure. Lesson opening and running strategies were clear that some planned lesson activities had not been completed. The transitions were smooth. There was some variety of lesson activities, with the teacher telling stories to engage pupils with core concepts, asking them to write based on the instructions given. First, T4 made the students write sentences from the instructions given. Then he wanted the student to work in small groups to discuss the sentences. Fink (2005) discusses a teacher can ask a student to help them summarize, write down the main points on a piece of paper what they think are the main points of the lessons. The teachers can review the students' answers to gauge their understanding of the topic.

In T4 and T3's lesson, the lesson running was extracted as follows:

T4 and T3: Did you do your homework?

Ss: Yes! (Some students)

T4 and T3: Let us do the answers.

Ss: Yes!

T4 and T3: Open your book at page 136. Lesson Seven: Comparatives

Activity 1 . With a partner, discuss the following sentences.

The activities want the students to discuss the following sentences with their partners first and then the students are required to copy them into their exercise books. Let us see the extract.

Copy the following into your exercise book.

1. Hawi is younger than Tona.

2. Fatuma is fatter than Rebika.

3. Tiru is shorter than Chaka.

4. Hailemarian is younger than Tewabech.

5. Dibaba is smaller than Mezgebu.

Then the teacher wanted the students to compare the things in their class using "Than". Here is how the teacher gave the students examples. Here is the extract.

T4 and T3: Write 5 sentences using than to compare things in your class.

Example: A ruler is longer than a pencil. Who can write 5 sentences?

The observed data reveal that the observed teachers spent much of their time on Lesson Seven: Comparatives. From this extract, one can understand that there were no clear introductory and closure parts of the lesson. In fact, the teachers asked what the students learnt the day before to activate their prior knowledge as a lesson introduction. Questions can be asked to activate students' prior knowledge. But the teachers are expected to give students sometime to think about the answers. This finding is similar with Fink (2005) who states a teacher can gather background information from the students to shape introductory questions and learning activities to familiarize students with the topics of the lessons.

Transition from lesson introduction to lesson presentations was quick as it was not marked clearly and relatively smooth. Activities largely involved the teacher and questions to the whole class. There was no checking students' understanding of the 
lessons. The students were asked collectively. What was observed from the observed teachers was stated against what Fink (2005) reveals. Fink states that a teacher need to develop a creative introduction to the topic to stimulate interest and encourage thinking. You can use a variety of approaches to engage students. The data reveal that the teacher lacks this skill to do so. This might imply that the teacher is required further training courses in order to introduce, run and end the lessons. Besides, further professional development courses are needed to the teacher to develop pedagogic skills.

The data from the extract reveal that the observed teachers like other teachers began the lesson by questions. The questions were used to reminder of what the student wanted to do and how they want to do it. The teacher did not praise the students and posed the questions to the whole class. Fink (2005) offering praise for students' work and efforts so that students can begin to view their own intelligence as something that can be developed.

T3's and T4's lesson was Lesson Six: Using: What is your ... like? My...is.... on student textbook 135 . Here is what is extracted again:

T3 and T4: Today our Lesson is Gebeta: Week 11. Yesterday we learnt

about Birds and Frog. Read the topic Bontu.

Bontu: The Birds and Frog

T3: Very good, Bontu. Other students, who can try? Garuma?

Garuma: Writing Composition

T3: Good Garuma. What else did we learn yesterday? Lense?

Lense: Syllables.

T3: Excellent! Lense. Now, we are going to start Week 11: Gebeta

Week 11: Day 1. Open your book at Page 85.

A study by Fink (2005) reveals that a teacher has to prepare several different ways of explaining the material (real-life examples, analogies, visuals, etc.) to catch attention of students and appeal to different learning styles. Furthermore, the data show that the teachers appreciated the students who tried to answer the lesson opening questions saying, "Very Good", "Excellent" and "Good". Fink expresses that teacher praise is one of tools that can be a powerful motivator for the students during opening lessons. Research suggests that praise is used in both general and special education classroom in every stage of the lessons. These guides offer recommendation to instructors using praise to maximize its positive impact.

From the observation data, one can also understand that transitions were not well organized. Due to lack of clarity of starting new lessons, the teacher got limited students' response. The lesson task involved varied teaching approach (direct instruction at the beginning and end). Much of the lesson time involved students working in groups. Although there was little evidence of checking students' understanding, students' learning needs, achieving the lesson objectives. Fink (2005) states a teacher has to design and identify strategies to check students' understanding. Checking students understanding of the lessons helps the teachers to design learning activities.

Brown (2001) hold a similar opinion that teachers can begin to establish a positive learning environment by showing their passion for the subject matter, using student names, reinforcing student participation during class, and being 
active in moving among the students. This implies that if the teachers are provided further development courses on this area, they would do more than what they are doing now.

T2 was observed while teaching '-ing form of Verbs'. The teachers used nearly similar kind of lesson presentation. They asked the students to tell the class about words containing -ing. It was observed that the students were actively participating in telling the teachers verbs containing -ing. The teachers wrote students answers which are verbs containing -ing. The teachers used different kinds of questioning techniques to ask the students. T2 used the same kind of question to ask the students. The extract from T2 was taken as follows.

\section{T2: Tell me word that have -ing. Tell me. Tell me. Who?}

The data reveal that all the observed teachers called their students who they wanted to answer the question. Although the three observed teachers differ in asking the number of who would answer the questions, all the students handed up to answer the teachers' questions. This reveals that students' participation was high. The implication is the teachers did well enough in the observed classes. This shows that the teachers already know the importance of calling students in their names when they ask questions. Asking students in their names fosters a more interpersonal relationship, removes language barriers, and puts students in a better position to take charge of their learning and feel more confident to question their teachers.

Willemsen (1995) states many successful educators agree that learning students' names is fundamental to developing a sense of community in the classroom. Willemsen further points out that a teacher that doesn't take the time to learn their students' names is often perceived as disinterested and unapproachable. This means by calling on a student by name, it gives the impression that the teacher cares about their success and develops a sense of trust. This also has an effect on student interactions. Syverud (1993) holds a similar opinion in stating that knowing the names of peers by either activity in which they learn each other's names or by hearing the teacher address them promotes interaction between students. Syverud also states that when the professor engages the student in personal conversation, recognizes the students by names, and seems to include them in the domain of attention, the subject matter seems more accessible.

The data from the observed teachers reveal that T2 did not do well enough on grammar usages when they asked the questions. The teacher lacked the knowledge needed to use appropriate subject-verb agreement. Had the teachers used "...word that has...or ...words that have, it could have been better. This means the teachers are required to get further development courses on subject- verb agreement. Offering the teachers with further training courses on grammar lessons would equip the teachers with the knowledge they needed to teach English.

The observation data show that the teachers do have problem of applying Subject-Verb- Agreement. The teachers' use of singular subject with the plural verb shows the teachers have grammar problems. Had the teachers used "Tell me words that have -ing" or "Tell me a word that has -ing", they would have been correct. To use appropriate grammar when they teach, instruct, the teachers are required to develop professionally on grammar lessons. The observation data also reveal that the observed teachers wrote words containing -ing on the blackboard and instructed students to copy the words from the board. Here is an extract from of the teachers' lesson running. 
T1 and T2: Tell me the -ing form of read, study, come and go" Almaz, can you answer the - ing form of read?

S1: Reading.

T1 and T2: excellent. Chala, what is the -ing form of the study?

S2: Studying.

T1 andT2: Very Good. Who can tell me the -ing form of come? Burtukan?

S3: Coming.

The data show that $\mathrm{T} 1$ and $\mathrm{T} 2$ asked the students the question. But they become askers and answerers of the question. The students could have done by themselves to find the answers which the teachers required the students to solve. This seems the teachers poorly performed the lesson. This might be due to teachers' lack of the knowledge or pedagogic skills they are required to apply to enhance classroom activities. This might imply that the teachers play a dominant role in the English classes they were teaching. Further professional development training courses on students centered method of teaching English language would equip the teachers with knowledge and the skills they are required to apply in the classes.

After the class, T1 and T2 were asked to reflect on why they did not allow students to try to the -ing form of the words the students were given. The teachers reflected that if they were given this opportunity, the students would disturb by shouting loudly. From the teachers' reflections, one can observe that the students' lack of discipline and attention during the lesson are some of the challenges that had worried the teacher. My observation data of the classes reveal that no noticeable disruption in the progress of the lesson occurred when the teachers form the -ing form of the words themselves. This implies that the T1 and T2 did not do well enough in allowing the students to discuss the question and to find the answers by themselves. Therefore, continuous professional development courses on active learning strategies of teaching English will equip the teachers with the required pedagogic skills to apply new knowledge so that the teachers build their skills set and knowledge about lesson running

\subsection{THE NATURE OF THE TEACHERS' LESSON ENDING}

The lesson ending by T1, T2 and T3, T4 was extracted below.

T1, T2 and T3, T4: open your book on page-----. And copy activities One and Two into your exercise books and do the activities for tomorrow.

The observation data from the extract reveal that the teachers tried to tell the students what they are going to do for the next classes. They tried to inform the students as they should copy the activities into their exercise books and do the answers to the activities as they are instructed in the student textbook. The classroom observation data exposed that the observed teachers did not try to give the students a general summary of the lesson of the day. Besides, it seems to me that the teachers did not check whether the students have understood the main points of the lesson of the day or not. Not doing so means that the teachers did not recap the main points of the lesson of the day. This means the teacher could not do well enough in the end the lesson ending. This implies that the teachers are required to get CPD opportunities on the lessons would be brought to an end.

In order to check students understanding of the lesson, the teacher asked the whole class weather they had questions. Most students raised hands to volunteer 
answers and many of them answered simultaneously. The students seemed almost engage with tasks. Students' eagerness to answer the question reveals that there was a high degree of individual involvement. Fink (2005) states that the best way to end a lesson is to give students some kind of review activity so that they may see the progress the students have made in just one lesson. One of the most common and easiest to implement is simply taking the last 5 minutes of class to ask your students, "What have you learned today?" What the classroom observation data tell us about the teachers' professional development needs are summarized as follows.

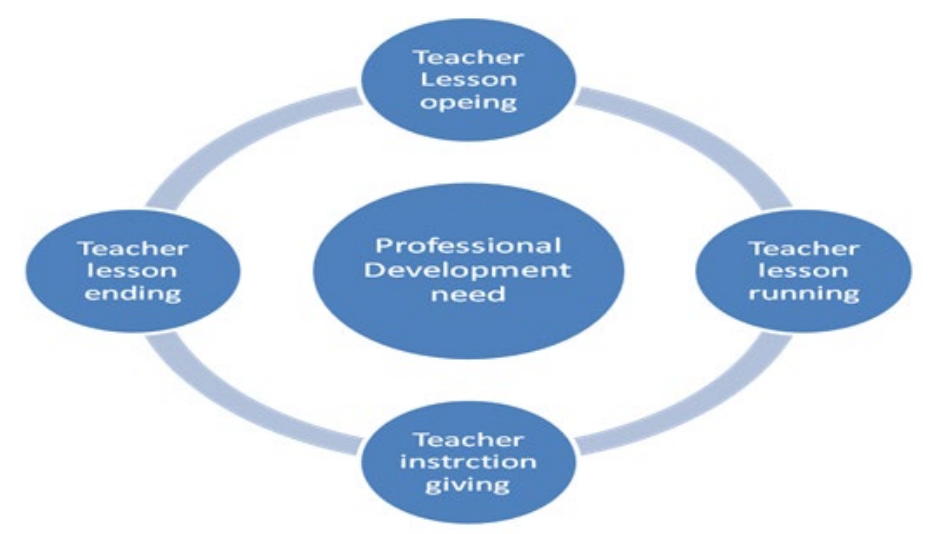

Figure 1 Teacher professional development needs areas

The implication of this is the teachers are required their skill set and stay up to date on school trends, increase their own teaching performances and adding to the school value. The response exposed both young and experienced English language teachers to new ideas, solidify the knowledge and increase their experts on how the lessons run. To put it in nutshell, opportunities like workshops, conferences and other networking events allow English language teachers to branch out to meet learning needs. This means new skills acquired through professional development training can be critical to opening new doors within the field.

\section{REFERENCES}

Abosnan, H. (2016). The Teaching of Reading English in a Foreign Language in Libyan Universities : Methods and Models. Unpublished PhD Thesis: University of Glasgow. Retrieved from https://theses.gla.ac.uk/7829/

Abraham Tulu (2018). The practice and challenges of school-based teachers' continuous professional development : A case of Government Secondary Schools of Hawassa City in Ethiopia. School of Teachers Education, College of Education, Hawassa University, Ethiopia. Retrieved from https://doi.org/10.5897/ERR2018.3646

Bernstein, B. (2000). Pedagogy, symbolic control and identity. Lanham: Rowman and Littlefield Publishers Inc.

Blay, J. A. and Ireson,J. (2009). "Pedagogical Beliefs, activity, choice and structure, and adult-child interaction in nursery classrooms". Teaching and Teacher Education (25) :1105-1116. Retrieved from https://doi.org/10.1016/j.tate.2009.03.009 
Bohlke, D.\& Richard, C. J. (2011). Creating Effective Language Lessons. New York: Cambridge University Press.

Brown, H. (2001). Teaching by principles: An interactive approach to language pedagogy. White Plains, NY : Addison Wesley Longman, Inc, 2001.

Butler, G., (2015). English language education among young learners in East Asia : à review of current research (2004-2014). Language Teaching, 48, 303-342. Retrieved from https://doi.org/10.1017/S0261444815000105

Cheng, Y., (2010). A case study on foreign English teachers' challenges in Taiwan elementary schools. System, 38, 41-49. Retrieved from https://doi.org/10.1016/j.system.2009.12.004

Clark, T. (2018). Key Challenges and Pedagogical Implications : International Teacher Perspectives. Cambridge Assessment English internal report

Darling-Hammond, L. (2000). Teacher quality and student achievement: A review of state policy evidence. Education Policy Analysis Archives, 8(1), 1-44. Retrieved from https://doi.org/10.14507/epaa.v8n1.2000

Dereje Taye. (2015). School Based Continuous Professional Development Practices at a Selected General Secondary and Preparatory School in Bahir Dar Town. Bahir Dar Journal of Education. Retrieved from https://d1wqtxts1xzle7.cloudfront.net/60208155/BJE-

Vol15No2DerejeTayeWondem20190805-107921-vq5it-with-cover-pagev2.pdf?Expires=1645768435\&Signature $=$ GUdbWGHBBWWsGJwsuPqxJ0aa DK9vH8mYQ73FVX $\mathrm{H}-$

OWn0yHkm7AGZ0m2gPrU0qhJP5s JlMWBEZ8WXLD2uuSPMCaGFKFmrx D1FgOv8uyuyz rpGuKJLyQpNvIOFPwXOqw69d1a602gsf7mgmhSikvRHii LhpJrHw1990jRjnRLYxogy9Y46gpjKznbZ0E09msaCSPJmWFANUNy39JkA1iZ7nGNMbt50i8NjQVfTWKw73o2pKbpCx3FHhC81h03uAY6ZX2Vfz4TylcL2mAT Ml0Luh6mSjR7 QNN1rllUsex1SKUQ0k0hHa7sCIABOmYkMIquNeQdcKgQ UTGIkUFRA_\&Key-Pair-Id=APKAJLOHF5GGSLRBV4ZA

Desta, D., Chalchisa, D. \& Legesse, G. (2013) School-based Continuous Teacher Professional Development in Addis Ababa. Journal of international Cooperation in education, 15(3), 77-94.

Eba, M. (2013). The Need for Professional Growth of ELT Teachers in Ethiopia. Science, Technology and Arts Research Journal. Retrieved from https://www.ajol.info/index.php/star/article/view/98764

Eksi, G. and Cape, Y. (2012). English Instructors professional development needs areas and predictors of professional development needs. Marmara University press. Retrieved from https://doi.org/10.1016/j.sbspro.2013.01.108

Fekede T., \& Fiorucci, M. (2012). Examining Quality Issues in Primary Schools in Ethiopia : Implication for the Attainment of the Education for All Goals. Journal of Educational, Cultural and Psychological Studies, 5,129-150. Retrieved from https://www.ledonline.it/index.php/ECPSJournal/article/view/501

Fekede Tuli and Pavi, T. (2015). Professional Learning of teaches in Ethiopia : challenges and implications for reform. Australian Journal of Edcuation. Retrieved https://search.informit.org/doi/abs/10.3316/ielapa.204370559175669 
Fink, L., (2005). Integrated course design. Manhattan, KS : The IDEA Center.

Hedge, T. (2000) Teaching and learning in the language classroom. Oxford : Oxford University Press.

Hismanoglua, M. (2010). Effective professional development strategies of English language teachers. À European University of Lefke, Faculty of Arts and Sciences. Retrieved from https://doi.org/10.1016/j.sbspro.2010.03.139

Jingxia. L. \& Jing. H. (2015) How to Have à Good Lead-in in English Classrooms, China Three Gorges University, China.

Lemlem, T. (2010). Review of some recent literature: Identifying Factors that Affect Ethiopia's Education Crisis. Ethiopian E-Journal for Research and Innovative Foresight, 2(2), 56-68.

Lindsay, C. (2006) Learning and Teaching English : A Course for Teachers, Oxford University Press, Oxford, pp. 108-110.

Luis, D. (2017). How do Teachers Make Sense of Peer Observation Professional Development in an Urban School $\mathrm{P}$ :255. Retrieved from https://doi.org/10.5539/ies.v10n1p255

Mann, S. (2005). The language teacher's development. Language Teaching, 38(3), 103-118. Retrieved from https://doi.org/10.1017/S0261444805002867

Minae, I. and David, K. (2017). Teacher Professional Development Needs for Pedagogical ICT Integration in Kenya : Lessons for Transformation. European Journal of Education Studies. Retrieved from https://www.oapub.org/edu/index.php/ejes/article/view/787

Ministry of Education (MOE) (2010). General Education Quality Improvement Package. Addis Ababa : GT press.

Ministry of Education (MOE) (2013). School Improvement Program Guidelines : improving the quality of education and Students results for all children at primary and secondary schools. A.A:GT press.

Ministry of Education, (MOE) (2014). Evaluative Research of the General Education System in Ethiopia : A Quality Study. Addis Ababa

Mnistry of Education, (MOE) (2005). Educational statistic annual abstract. Addis Ababa, Ethiopia : Education Management and Information Systems

Naom, M. (2013). Continuing Professional Development Needs For English Language Teachers In Kenya. International Journal Of Research In Social Sciences.

Richards, K. (2006). "Being the teacher : identity and classroom conversation". Oxford Journals 27 (1) : 51-77. Retrieved from https://doi.org/10.1093/applin/ami041

Rukia Hassan, (2014). Female Teachers' professional Development. Through Action research.

Scrivener, J. (2012) Classroom Management Techniques : Cambridge Handbooks for Language Teachers, Cambridge University Press, UK, pp. 236, 246.

Suwaed, H. (2011). Teachers' Cognition and Classroom Teaching Practice : an Investigation of Teaching English Writing at the University Level in Libya. Unpublished $\mathrm{PhD}$ Thesis : University of Glasgow. Retrieved from https: //theses.gla.ac.uk/2963/ 
Syverud, K. (1993) "Taking Students Seriously : A Guide for New Law Teachers." J. Legal Education, 43, 247. Retrieved from https://heinonline.org/HOL/LandingPage?handle=hein.journals/jled43\&d iv $=27 \&$ id $=\&$ page $=$

Tadele Zewdie (2013). Teacher Induction and the CPD of Teachers in Ethiopia.

Tessema, K. (2006). Contradictions, challenges, and chaos in Ethiopian teacher education Journal for Critical Education Policy Studies.

Watson, R. (1997) Classroom Teaching Strategies, Prentice Hall, Europe, pp. 14-23.

Willemsen, E. (1995). "So What is the Problem ? Difficulties at the Gate." Fostering Student Success in Quantitative Gateway Courses, 61, 15-21. (Pp. 15-21). Retrieved from https://doi.org/10.1002/tl.37219956105

Workneh Abebe and Tassew Woldehanna (2013). Teacher Training and Development in Ethiopia Improving Education Quality by Developing Teacher Skills, Attitudes and Work Conditions. Retrieved from https://www.younglives.org.uk/sites/www.younglives.org.uk/files/YLWP103_Abebe-Woldehanna-Teacher-Training.pdf

Zein, M. (2015). Factors affecting the professional development of elementary English teachers. Professional Development in Education. Retrieved from https://doi.org/10.1080/19415257.2015.1005243

Zein, M. (2016). Professional development needs of primary EFL teachers : perspectives of teachers and teacher educators. Asia Pacific Journal of Education. Retrieved from https://doi.org/10.1080/19415257.2016.1156013

Zhao, B., (2009). Corrective feedback and learner uptake in primary school EFL class rooms in China. The Journal of Asia TEFL, 6 (3), 45-72. Retrieved from https://www.proquest.com/openview/dbdae85df8455d5e5a6063ba8b90 92e5/1?pq-origsite=gscholar\&cbl=4424407 